\title{
Molecular Evaluation of Two Common Trigonella Species (Trifoleae - Fabaceae) in Egypt
}

\author{
Hisham A. R. Deif*1, Ream I. Marzouk ${ }^{2}$ and Laila M. El- \\ Sadek $^{3}$
}

Botany Department, Faculty of Science, University of Alexandria, Egypt

*1'Corresponding author email: hmdeif@hotmail.com

${ }^{2}$ email: reammarzouk@yahoo.com, ${ }^{3}$ email: ayyad31@hotmail.com

Hisham A. R. Deif, Ream I. Marzouk and Laila M. El-Sadek, 2010. Molecular Evaluation of Two Common Trigonella Species (Trifoleae - Fabaceae) IN EGYPT. Taeckholmia 30: 81-97.

\begin{abstract}
RAPD analyses were used to assess the inter- and intraspecific variations among eight different populations of the two most widely distributed Trigonella species in Egypt, Trigonella maritima and Trigonella stellata. Thirteen primers effectively primed genomic DNA samples of $T$. maritima and $T$. stellata populations, and resulted in a total of 196 polymorphic bands. All primers revealed considerable polymorphism. In the four populations of T. maritima a total of 165 bands were produced with a percentage of polymorphism ranging between $22.4 \%$ for Matruh population to $28.5 \%$ for Fuka population. On the other hand, a total of 164 bands were produced in the four populations of $T$. stellata generated with a percentage of polymorphism ranging between $26.2 \%$ to $30.5 \%$ in Salheya and Sinai populations, respectively. The data were analyzed using the UPGMA (Unweighted Pair Group Method with Arithmatic Mean) method, which indicated that the eight populations of these two species could be considered as biotypes
\end{abstract}

Key Words: Trigonella maritima, Trigonella stellata, RAPD analyses, Biotypes, Polymorphism 


\section{Introduction}

Plant genetic resources are being eroded through destruction and degradation of natural habitats, intensification of arable land and marginal areas cultivation, woodcutting, and overgrazing of natural pastures and range lands (Praciak, 1996; Tantawi, 2001; Blanco, and Lal, 2008). This anthropogenic interference occurred on large scale especially in the Egyptian Mediterranean area. This led to habitat degradation and fragmentation which may restrict gene flow and result in genetic diversity among populations that previously did not exist (El-Sadek and Ayyad, 2000). In turn, this may affect the life history traits and the probability of species extinction (Bawa et al., 1991). In Egypt, due to man's disruptive activities by changing patterns of land use, the genus Trigonella is subjected to deterioration. Accordingly, research dealing with the conservation of the genetic resources of this genus become of prime importance. Also, wild Trigonella species in the local flora can be considered as wild ancestors or close relatives of cultivated legumes (e.g. Medicago, Trifolium and Melilotus), and a source of desirable genes for cultivated varieties. Besides, the populations of these wild species include genetic traits of adaptation to environmental stresses, like drought and salinity resistance, that can be valuable in genetic engineering of cultivated varieties (Barkoudah, 1996).

The genus Trigonella includes species of considerable economic value for grazing and medicinal purposes (Townsend, 1974; Chiej, 1988). Consequently, it is necessary to evaluate the genetic resources of its widely distributed species to provide the basis for their propagation, conservation and for future efficient utilization. Conceivably, such evaluation depends mainly on sound taxonomic knowledge of the studied species (Frankel and Bennett, 1970; Jana et al., 1990; Damania, 2008).

Molecular biology have introduced polymerase chain reaction (PCR) and random amplified polymorphic DNA (RAPD) markers to obtain the DNA sequence information required to generate genome specific fingerprints (Innis et al., 1990; Hoelzel and Green, 1992). Polymorphisms found among RAPD profiles can serve as genetic markers and has been widely used in the identification and differentiation among many plant species (Demeke and Adames, 1994; Bena, 2001; Deif, 2002; Dangi et al., 2004; Hammad, I. 2009).

Molecular characters evolve at higher rates than morphological, physiological and karyotypic characters with great diversity represented within and among loci within the genome (Bisby, 1995; Karp et al., 1996). 
Molecular characters can serve to identify varieties within species and also make out species boundaries, thus contribute to the identification of resource populations. It also can identify morphologically cryptic species which may go unrecognized or which may be inappropriately mixed with genetically unrelated populations (Stock and Samways, 1995). Since 1997, molecular markers are used as important criteria to be considered during the process of listing endangered species under plant protection legislation (Geburek, 1997).

According to our knowledge, molecular information about DNA of the two Trigonella species, T. maritima and $T$. stellata is still not available. Consequently, genomic DNA isolated from leaf samples were used for RAPD analyses to assess the inter- and intra-specific variations among the studied taxa in order to provide basic information for evaluating their genetic recourses, and to determine the genetic relatedness among their different populations.

\section{Materials and methods}

Dry leaves of 6 replicas collected from four populations of Trigonella maritima (Matruh, Fuka, Ras El-Hekma and Hawaraya) and the four populations of Trigonella stellata (Matruh, Fuka, Salheya and Sinai) were used for DNA extraction (Appendix 1). Isolation of DNA from one-gram dry leaves was carried out using cetyltrimethyl ammonium bromide (CTAB) method (Doyle and Doyle, 1990). Thirteen primers (Operon 10-Mer kits; Table 1) were used for molecular characterization. Amplification reaction was carried out as described by Bagheri et al. (1995). Each reaction mixture of $50 \mu$ l contained $30 \mathrm{ng}$ genomic DNA, IX Taq DNA polymerase buffer, $100 \mathrm{mM}$ of each dNTP's [(dATP, dCTP, dTTP and dGTP) Pharmacial, $1 \mathrm{mM} \mathrm{MgCl} 20.2 \mathrm{mM}$ of primer (Operon 10-Mer kits), 5 units of Taq DNA polymerase (Promega Crop., Madison, WI, USA), and deionized double distilled $\mathrm{H}_{2} \mathrm{O}$ up to $50 \mu \mathrm{l}$. PCR amplification was performed in Perkin-Elmer Cetus DNA Thermal Cycler for 35 cycles after initial denaturation for 3 min. at $94^{\circ} \mathrm{C}$. Each cycle consisted of denaturation cycle for half a minute at $94^{\circ} \mathrm{C}$, annealing for $1 \mathrm{~min}$. at $50^{\circ} \mathrm{C}$, and extension for $1 \mathrm{~min}$. at $74^{\circ} \mathrm{C}$. Amplification products were analyzed by electrophoresis in a $1 \%$ agarose gel, supplemented with ethidium bromide $(0.5 \mu \mathrm{g} / \mathrm{ml})$. Standard DNA marker (mixture of $\lambda$ Hind III and $\Phi \times 174$ DNA/Hae III) was loaded on the first well of the gel. The gels were examined on UV transilluminator filter by ultraviolet light (302 $\mathrm{nm}$ wavelength) and photographed using Polaroid 
film type 57 (ASA 3000) (Sambrook et al., 1989). For data analysis, sharp discrete bands were scored as binary characters. Total number of bands produced per each primer, the percentage of polymorphic bands, and the number of unique bands were recorded for each population of T. maritima and T. stellata.

The MEGA (Molecular Evolution Genetic Analysis; Sudhir et al., 1993) and Systat version 11 (Wilkinson, et al., 2004) programs were used to compute genetic distances. The UPGMA method was used to generate the dendrogram.

\section{Results}

Thirteen Operon primers effectively primed the amplification of genomic DNA samples of the eight populations of both T. maritima and $T$. stellata. This resulted in a total of 196 polymorphic bands; of these, 50 bands were common between the populations of the two species. An average of 12 discrete DNA products was generated per primer with a range from 8 to 17 bands. RAPD patterns of two representative primers, A-14 and A-17, are demonstrated in Plate 1, while the band information on both $T$. maritima and T. stellata are presented in Table 2 and 3, respectively.

The four populations of $T$. maritima generated a total of 165 bands. The discrete DNA products per primer ranged from 8 bands generated with primer number $\mathrm{H}-01$ to 17 bands generated with primer number $\mathrm{B}-20$. The total number of bands generated for each population ranged from 104 bands produced in Matruh populations to 114 bands produced in Fuka population. All primers generated common bands for the four studied populations except primer number B-17. Common bands ranged from one band generated from primers numbered $\mathrm{H}-03$ and $\mathrm{A}-06$ to 10 bands generated by primer D-01. The mean percentage of polymorphic bands ranged from $22.4 \%$ for Matruh population to $28.5 \%$ for Fuka population.

On the other hand, the four populations of $T$. stellata generated a total of 164 bands. The discrete DNA products per primer ranged from 8 bands generated with primer number B-17 to 16 bands generated with primers numbered A-06, A-17 and B-20. The total number of bands for each population ranged from 110 bands (Salheya population) to 117 bands (Sinai population). Common bands ranged from 2 bands produced by primer $\mathrm{H}-03$ to 8 bands produced with the two primers C-08 and D-18. The mean percentage of polymorphic bands ranged from $26.2 \%$ in Salheya population to $30.5 \%$ in Sinai population. Different $T$. stellata populations were 
distinguished by species specific bands, a maximum of 6 bands generated from primer number in Sinai population.

The cluster analyses constructed by using both MEGA and Systat programs succeeded in the segregation of different populations within the two studied species in a consensus manner.

The dendrogram, based on RAPD analysis using UPGMA method for $T$. maritima resulted in the separation of Hawaraya population from the other three populations at a relatively high genetic distance $(0.143$; Figure 1a). Ras El-Hekma population was also distinguished at 0.133 genetic distance from the Matruh and Fuka populations. The latter two populations were discriminated at a genetic distance of 0.116 .

The relationships among the four populations of T. stellata (Figure 1b) illustrated that Sinai population was segregated from the other studied populations at a relatively high genetic distance (0.173). Salheya population was separated from both Fuka and Matruh populations at 0.102 genetic distance. On the other hand, Fuka and Matruh populations were discriminated at a relatively lower genetic distance.

Pooling all the RAPD data in one analysis produced the dendrogram illustrated in Figure 1c. The relationships in this dendrogram showed high concordance with the constructed trees for each species separately. However, Sinai population of $T$. stellata separated in one group from the other studied populations of the two species at a relatively high genetic distance (0.186). At the same time, the populations of the two species form two subgroups at genetic distance of 0.149 .

\section{Discussion}

RAPD markers are mostly dominant and inherited in Mendelian fashion (Williams et al., 1990). RAPD analysis has been rated as a valuable and suitable technique for studying genetic diversity at the population level (Deif et al., 1998; Khalil, 1999; Heikal et al., 2008). However, it will be erroneous to think that because RAPD analysis reveals characters in the DNA, which are necessarily superior to those revealed by other molecular methods (Karp et al., 1996) or morphological ones.

In a previous study Ahmed and Marzouk (2002), used 98 morphological characters to distinguish among different morphological populations found at different geographic regions of both T. maritima at Matruh, Fuka, Ras ElHekma and Hawaraya and T. stellata at Matruh, Fuka, Salheya and Sinai. However, the morphological data seemed to be inadequate for 
distinguishing between them. Using RAPD markers herein confirmed the distinction among these populations (Figure 1). The use of RAPD markers to determine the relationship between genetic diversity and geographic variations was confirmed by (Brauner et al., 1992; Echt et al., 1992; Yu and Pauls, 1993; Brummer et al., 1995; Godt and Hamrick, 1996; Subramanian et al., 2000; Dangi, 2004 and McCormick et al., 2009).

The methodology used in the present study; bulked DNA sampling, and using 13 Operon primers generating 246 RAPD bands, appeared to be sufficient to informative results. The Operon primer D-01 produced the highest number of shared bands (10 bands) in the studied T. maritima populations. While Operon primers C-08 and D-18 produced the highest number of shared bands ( 8 bands) in studied T. stellata populations. Consequently, it is recommended to use this primers for specifying the two studied species. These primers can amplify DNA sequences that are highly conserved, and thus help to generate polymorphism at species level as established by Deif et al. (1998) on Orobanche species.

The total number of RAPD bands generated from the four studied $T$. maritima populations were 165 bands, out of which 67 bands were common. The highest percentages of polymorphic bands produced in T. maritima populations $(61.50 \%$ and $50 \%)$ were obtained with Operon primers A-06 and B-17 for Matruh and Hawaraya populations respectively. While it was $69.20 \%$ and $46.20 \%$ with Operon primer H-03, for both Fuka and Ras ElHekma populations, respectively.

However, the total number of RAPD bands generated from the four studied T. stellata populations were 164 bands, out of which 67 bands were common. The highest percentages of polymorphic bands $(61.50 \%)$ were obtained with Operon primer $\mathrm{H}-03$ for both Matruh and Fuka populations. While it was $43.80 \%$ and $76.90 \%$ with the Operon primers B-20 and $\mathrm{H}-02$ for Salheya and Sinai populations, respectively. These RAPD primers can amplify DNA sequences that are highly variable. Therefore, they are useful for classification at population level (below species level; Adames and Demeke, 1993; Deif et al., 1998).

The dendrogram discriminated Sinai population of T. stellata as one group at a relatively high genetic distance $(0.186)$ from all T. maritima and $T$. stellata populations. The present study reveals that it is characterized by the highest mean percentage of polymorphism (30.5\%), the greatest number of species specific bands ( 23 bands), and consequently results in a relatively high genetic distance. These results are in agreement with El-Sadek and 
Bidak (1994) who found that Sinai population of $T$. stellata was characterized by highly significant differences in total chromosome length compared to populations from other geographic locations as Mariut, and Alexandria-Cairo desert road. The congruence of the discrimination of this geographic group by morphological and RAPD markers with cytogenetic data suggest that geographic isolation strongly influenced the evolution of this population.

In conclution, the present investigation indicates strong association between geographic distances and genetic distances for the populations of the two studied species (T. maritima and T. stellata). Moreover, it indicates that the eight populations of these two species can be considered as biotypes. This confirms that the RAPD technique is useful for characterization of the two species with their populations.

From the course of the present study two points may be highlighted: 1) the genetic diversity assessment of the two widely distributed species, $T$. maritima and $T$. stellata, indicates, the presence of four different biotypes for each of T. maritima populations (Matruh, Fuka, Ras El-Hekma and Hawaraya) and T. stellata populations (Matruh, Fuka, Salheya and Sinai) is confirmed, and 2) the priority should be given to studies on populations rather than whole species or higher taxa when germplasm collections are considered.

\section{Acknowledgements}

The authors are greatly appreciated to Professor Manal Fawzy Ahmed, Professor of Plant Ecology, Department of Environmental Sciences, Faculty of Science, University of Alexandria, Egypt, for her kind help during the field trips, and the identification of the collected taxa. Thanks are also extended to Mr. Khalid Radwan, researcher, Agricultural Genetic Engineering Research Institute (AGERI), for advice on performing the RAPD-PCR analyses for the studied taxa.

\section{References}

Adams, R.P. and Demeke, T. 1993. Systematic relationships in Juniperus based on random amplified polymorphic DNA. Taxon 42: 553-560. Ahmed, M.F. and Marzouk, R.I. 2002. A numerical taxonomic study on the genus Trigonella L. (Leguminosae) in Egypt. Proceeding of the second International Conference of Biological Sciences (ICBS). Faculty of Science, Tanta University 2: 189-222. 
Bagheri, A.; Paul, J.G.; Langridge, P. and Rathjen, A.J. 1995. Genetic distance detected with RAPD markers among selected Australian commercial varieties and boron-tolerant exotic germplasm of Pea (Pisum sativum L.). Molecular Breeding 1: 193-197.

Barakoudah, Y. 1996. Plant genetic resources in the flora of arid lands of the Mediterranean region. In: Batanouny, K.H. and Ghabbour, S.I. (Eds.). Arid Lands Biodiversity in North Africa: Proceeding of the Workshop, 14-16 November 1994. Cairo, Egypt 111-119.

Bawa, K.; Schall, B.; Solbrig, O.T. Stearns, S.; Templeton, A. and Vida, G. 1991. Biodiversity from the genus to the species. In: O.T. Solbrig (Ed.). From Genes to Ecosystems. A Research Agenda for Biodiversity, Report of IUBS-SCOPE-UNESCO Workshop. IUBS, Cambridge, MA 15-36.

Bena, G. 2001. Molecular phylogeny supports the morphologically based taxonomic transfer of the "medicagoid" Trigonella species to the genus Medicago L. Plant Systematics and Evolution 299 (3-4): 217 236.

Bisby, F.A. 1995. Characterization of biodiversity. In: Heywood V.H. (Ed.). Global biodiversity assessment. Cambridge UK: Cambridge University Pr. 21-106.

Blanco, H. and Lal, R. 2008. Erosion on Grazing Lands. Principles of Soil Conservation and Management. Springer Netherlands 345-373.

Brauner, S.; Crawford, D.J. and Stuesy, T.F. 1992. Ribosomal DNA and RAPD variation in the rare plant family Lactoridaceae. American Journal of Botany 79: 1436.

Brummer, E.C.; Bouton, J.H. and Kochert, G. 1995. Analysis of annual Medicago species using RAPD markers. Genome 38: 362-367.

Chiej, R. 1998. The MacDonald Encyclopedia of Medicinal Plants. MacDonald \& Co. Ltd., London, UK.

Damania, A.B., 2008. History, achievements, and current status of genetic resources conservation. Agronomy Journal 100: S27-S39.

Dangi, R.S.; Lagu, M.D.; Choudhary, L.B.; Ranjekar, P.K. and Gupta V.S. 2004. Assessment of genetic diversity in Trigonella foenum-graecum and Trigonella caerulea using ISSR and RAPD markers. BioMed Central Plant Biology 4:13.

Deif, H.A.R. 2002. Genetic Relatedness Among Faba Beans and its Wild Relatives. Proceedings of the Second International Conference of 
Biological Sciences (ICBS), Faculty of Science, Tanta University (2829 April, 2002) Tanata, Egypt 2: 152-160.

--------; Pauls, K.P.; El-Sadek, L.M. and Al-Menoufi, O.A. 1998. Rapid estimation of genetic relatedness among three common Orobanche species in Egypt by random amplification using PCR technique. Proceeding of the International Congress on Molecular Genetics, University of Ain Shams (21-25 February, 1998) Cairo, Egypt 1: 219-229.

Demeke, T. and Adames, R.P. 1994. The use of PCR-RAPD analysis in plant taxonomy and evolution. In: Griffin, H. and Griffin, A.M. (Eds.). PCR Technology: Current Innovation. CRC Press. Norwich, U.K. 179-214.

Doyle, J.J. and Doyle, J.L. 1990. Isolation of plant DNA from fresh tissues. Focus 12 (1): 3-15.

Echt, C.S.; Erdahl, L.A. and McCoy, T.J. 1992. Genetic segregation of random amplified polymorphic DNA in diploid cultivated alfalfa. Genome 35: 84.

El-Sadek, L.M. and Ayyad, M.A. 2000. Genetic diversity as a basis component of biodiversity: Case studies in Egypt. In: Nordenstam, B.; El-Ghazaly, G; Kassas, M and Laurent, T. (Eds.). Plant Systematics for the $21^{\text {st }}$ Century. Portland Press. U.K. 239-250.

-.---.-.- and Bidak, L.M. 1994. Cytogenetic diversity in populations of Trigonella stellata in Egypt. Journal of Union of Arab Biologists 1(B), Botany 55-75.

Frankel, O.H.; and Bennett, E. 1970. Genetic resources in plants, their exploration and conservation. IBP Handbook; 11. International Biological Programme, Oxford, Blackwell, London.

Geburek, T. 1997. Isozymes and DNA markers in gene conservation of forest trees. Biodiversity and Conservation 6: 1639-1654.

Godt, Mary Jo W. and Hamrick, J.L. 1996. Genetic diversity and morphological differentiation in Liatris belleri (Asteraceae), a threatened plant species. Biodiversity and Conservation 5: 461-471.

Hammad, I. 2009. Genetic variation among Bougainvillea glabra cultivars (Nyctaginaceae) detected by RAPD markers and isozymes patterns. Research Journal of Agriculture and Biological Sciences 5 (1): 63-71. Heikal, A.H.; Abdel-Razzak, H.S. and Hafez, E.E. 2008. Assessment of genetic relationships among and within Cucurbita species using 
RAPD and ISSR markers. Journal of Applied Sciences Research 4 (5): 515-525.

Hoelzel, A.R. and Green, A. 1992. Analysis of population-level variation by sequencing PCR-amplified DNA. In: Hoelzel A.R. (Ed.). Molecular genetic analysis of population. Oxford University Press 159-188.

Innis, M.A.; Gelfand, D.H.; Sninsky, J.J. and White, T.J. 1990. PCR Protocoles: A guide to methods and application. Academic Press, New York.

Jana, S.; Srivastava, J.P.; Damania, A.B.; Clarke, J.M.; Yang, R.C. and Pecetti, L. 1990. Phenotypic diversity and associations of some drought related characters in durum wheat in the Mediterranean region. In: Srivastava, J.P. and Damania A.B. (Eds.). Wheat genetic resources: Meeting diverse needs. John Wiley \& Sons, Chichester, UK. 27- 43.

Karp, A.; Seberg, O. and Buiatti, M. 1996. Molecular techniques in assessment of botanical diversity. Annals of Botany 78: 143- 149.

Khalil, M.M. 1996. Morphological and genetic characterization of three Common species of genus Reseda L. in Egypt. Ph.D. Thesis., Alexandria University, Alexandria, Egypt.

McCormick K.M., Norton, R.M. and Eagles, H.A. 2009. Phenotypic variation within a fenugreek (Trigonella foenum-graecum L.) germplasm collection. II. Cultivar selection based on traits associated with seed yield. Genetic Resources and Crop Evolution 56: 651-661.

Praciak, A. 1996. Seed storage of plant genetic resources. Seed Science Research 6:71-75.

Sambrook, J.; Fritsch, E.F. and Maniatis, T. 1989. In: Molecular cloning. A Laboratory Manual. Cold Spring Harbor Laboratory Press, New York, USA.

Stock, N.E. and Samways, M.J. 1995. Inventorying and monitoring of biodiversity. In: Heywood, V.H. and Watson, R.T. (Eds.). Global Biodiversity Assessment. UNEP. Cambridge UK. 453-545

Subramanian, S.G.; Nageswara Rao, R.C. and Nigam, S.N. 2000. Identification of DNA polymorphism in cultivated groundnut using random amplified polymorphic DNA (RAPD) assay. Genome 43: 656660.

Sudhir, K.; Tamura, K. and Nei, M. 1993. Molecular evolutionary gene analysis (MEGA). Version 1.01. The Pennsylvania State University, University Park, PA, USA. 
Tantawi, A. B. 2001. Plant genetic resources related to rice breeding in Egypt. In: Rice genetic resources and breeding for Europe and other temperate areas. Proceedings of Eurorice 2001 Symposium (3-8 September, 2001) Krasnodar, Russia.

Townsend, C.C. 1974. Flora of Iraq. Vol. 3. Leguminales. Ministry of Agriculture and Agrarian Reform, Baghdad.

Wilkinson, L.; Hill, M. A.; Miceli, S.; Birkenbeuel, G.; and Vang, E. 2004. Systat for Windows, Version 11. Evanston, IL; Systat Inc., Illinois.

Williams, J.K.G.; Kubelik, A.R.; Livak, K.J.; Rafalski, J.A. and Tingey, S.V. 1990. DNA polymorphisms amplified by arbitrary primers are useful as genetic markers. Nucleic Acids Research 18: 6531-6535.

Yu, K.F. and Pauls, K.P. 1993. Rapid estimation of genetic relatedness among heterogeneous populations of alfalfa by random amplification of bulked genomic DNA samples. Theoretical And Applied Genetics 86: 788-79. 
Appendix 1. List of $T$. maritima and $T$ stellata populations used in RAPD analysis

\begin{tabular}{|c|c|c|c|c|c|}
\hline \multicolumn{2}{|c|}{ Population } & \multirow{2}{*}{$\begin{array}{l}\text { Taxa putative } \\
\text { identification }\end{array}$} & \multirow{2}{*}{ Habitat } & \multirow{2}{*}{$\begin{array}{l}\text { Replica } \\
\text { Number }\end{array}$} & \multirow{2}{*}{ Shert laformation } \\
\hline Number & Name & & & & \\
\hline \multirow{3}{*}{1} & \multirow{3}{*}{ Matruh } & \multirow{6}{*}{ T. maritima } & $\begin{array}{l}\text { Wadi Ashtan } \\
\text { (nadi bed) }\end{array}$ & 2 & \multirow{3}{*}{ R. Ibrahim (1.5-1906) } \\
\hline & & & $\begin{array}{l}\text { Wadi Ilabis } \\
\text { (wad bed) }\end{array}$ & 2 & \\
\hline & & & $\begin{array}{l}\text { Wadi Habis } \\
\text { (entry of the wadn) }\end{array}$ & 2 & \\
\hline 2 & Fuka & & $\begin{array}{l}\text { Fuka } \\
(100 \mathrm{~km} \text { Matruh-Alexandria } \\
\text { road) }\end{array}$ & 6 & \multirow{3}{*}{ R. Ibrahim (1-5.19\%6) } \\
\hline 3 & $\begin{array}{l}\text { Ras El- } \\
\text { Hekma }\end{array}$ & & $\begin{array}{l}\text { Ras El-Hlekma } \\
(10 \mathrm{~km} \text { from the sea) }\end{array}$ & 6 & \\
\hline 4 & Hawaraya & & Hawaraya & 6 & \\
\hline 5 & Matruh & \multirow{7}{*}{ T. stellata } & $\begin{array}{l}\text { Abu-lahu } \\
\text { (Matrih-Sallum road) }\end{array}$ & 6 & \multirow{3}{*}{ R. Ibrahim (1-5.1996) } \\
\hline 6 & Fuha & & $\begin{array}{l}\text { Fuka } \\
(106 \mathrm{~km} \text { Matruh-Alexandria } \\
\text { road })\end{array}$ & 6 & \\
\hline 7 & Salheya & & $\begin{array}{l}\text { El-Salheya } \\
(\text { New })\end{array}$ & 6 & \\
\hline \multirow{4}{*}{8} & \multirow{4}{*}{ Sinai } & & El-Arish & 1 & $\begin{array}{l}\text { J.R. Shabetai, } 659(17-3 \\
\text { 1928). Det. Per Lassen } \\
(18+1983)\end{array}$ \\
\hline & & & Nekhl North Central Sinai & 2 & M. Drar, $713(10-5-1939)$ \\
\hline & & & $\begin{array}{l}\text { North Abu Zenima South } \\
\text { Sinai }\end{array}$ & 2 & $\begin{array}{l}\text { S. Shalaby and A } \\
\text { Khattab, 705 }(1++1062) \\
\text { Det. Per L assen (18 } 4 \\
1983)\end{array}$ \\
\hline & & & Mitla Pass El-Shat Sinai & 1 & $\begin{array}{l}\text { I. Drar, } 638(10.5-1939) \\
\text { Det. Per Lassen (15 + } \\
19 \times 3)\end{array}$ \\
\hline
\end{tabular}


Table 1. Base sequences of Operon 10-Mer primers used in the RAPD analysis of the studied Trigonella species.

\begin{tabular}{|c|c|}
\hline Primer number & Primer sequences \\
\hline A-06 & GGTCCCTGAC \\
\hline A-14 & TCTGTGCTGG \\
\hline $\mathbf{A - 1 7}$ & GACCGCTTGT \\
\hline B-17 & AGGGAACGAG \\
\hline B-20 & GGACCCTTAC \\
\hline D-01 & TGGACCGGTG \\
\hline D-05 & ACCGCGAAGG \\
\hline D-18 & TGAGCGGACA \\
\hline G-15 & GAGAGCCAAC \\
\hline H-01 & ACTGGGACTC \\
\hline H-02 & GGTCGGAGAA \\
\hline H-03 & TCGGACGTGA \\
\hline & AGACGTCCAC \\
\hline
\end{tabular}



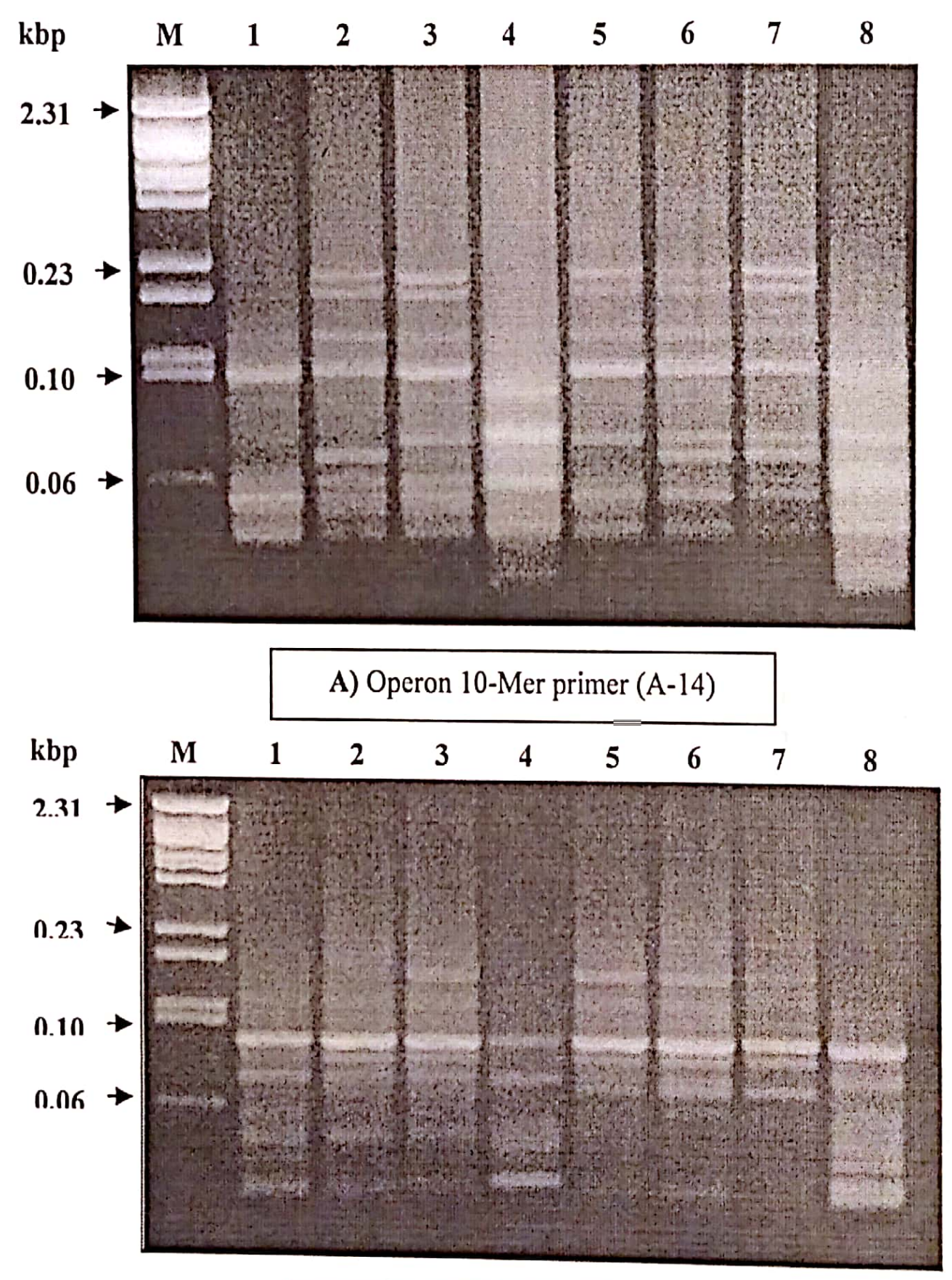

B) Operon 10-Mer primer (A-17)

Plate 1. A representative RAPD patterns obtained from genomic DNA for different populations of T. maritia and T. stellata primed with A) Operon A-14 primer B) Operon A-17 primer. Lane M, Molecular weight marker; Lane 1, T. maritima from Matruh population; Lane 2, T. maritima from Fuka population; Lane 3, T. maritima from Ras El-Hekma population; Lane 4, T. maritima from Hawaraya population; Lane 5, T. stellata from Matruh population; Lane 6, T. stellata from Fuka population; Lane 7, T. stellata from Salheya population; Lane 8, T. stellata from Saini population. kbp, Molecular weight markers in kilo base pair. 
Molecular Evaluation of Two Common Trigonella ......

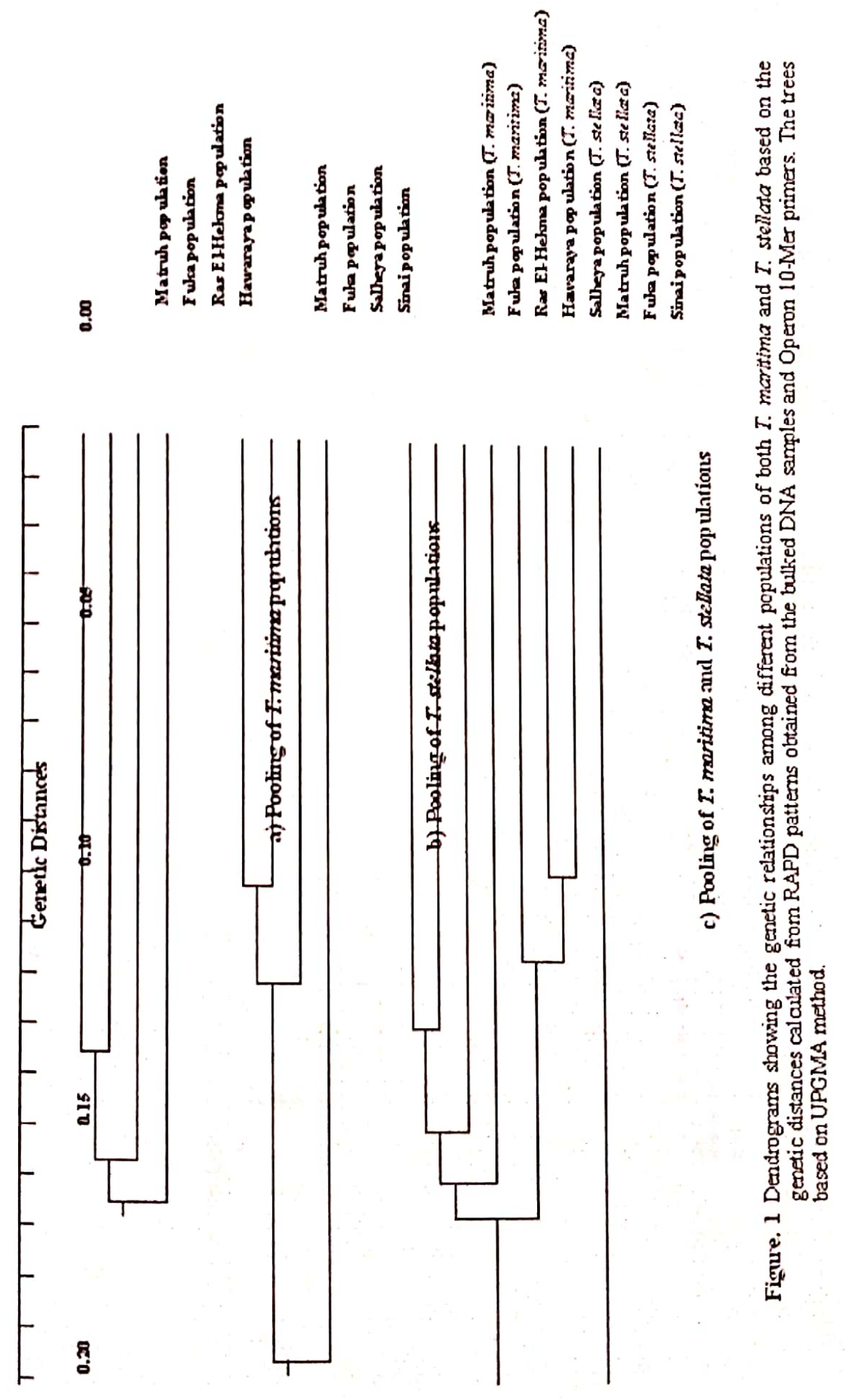




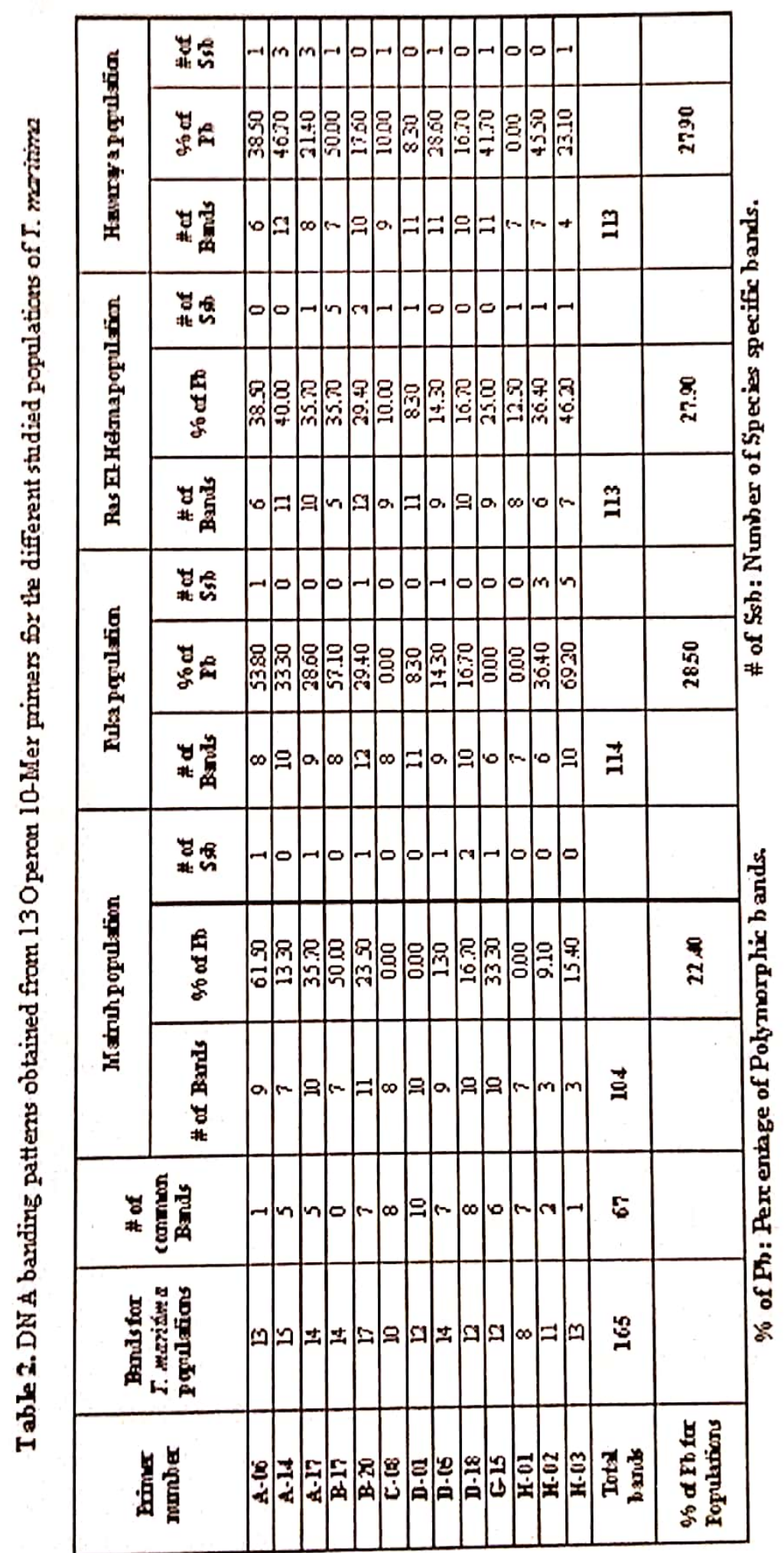




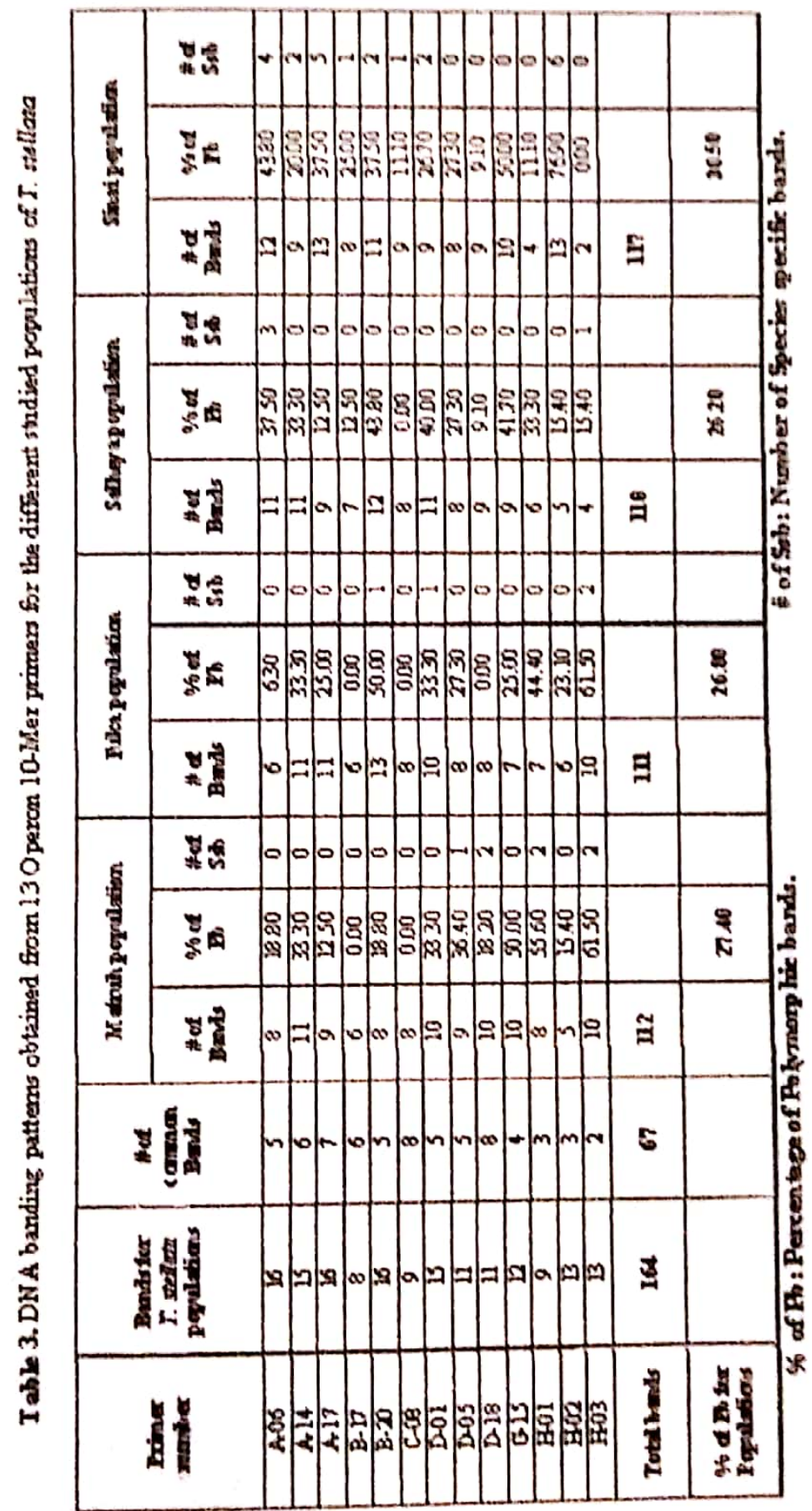

